\title{
Absorption of Gold from Colloidal Solutions by Fungi.
}

\author{
BY
}

MAUD WILLIAMS, B.Sc.

T $\mathrm{T}$ has been known for some time that colloidal preparations of gold pro-

1 duced by the addition of tannic acid tend to become mouldy, and that the mould, in course of time, removes the metal from the solution (1).

Upon the suggestion of $\mathrm{Mr}$. E. Hatschek an attempt was therefore made to find :

(a) if the same result could be obtained with solutions prepared by Zsigmondy's method (2) (addition of formaldehyde and sodium carbonate).

(b) what fungus or fungi could bring about the change."

(c) in what region the gold was retained.

\section{PREPARATIONS.}

A series of solutions was prepared by each method, the colours of the solutions ranging from red to blue, according to the sizes of the gold particles.

To solutions prepared by Zsigmondy's method, gum arabic was added to serve as a nutrient.

Spores of Penicillium glaucum, Aspergillus niger, and Oidium lactis were introduced into separate flasks of the solutions containing about 150 c.c. of liquid. Cotton-wool plugs were inserted and the flasks kept in darkness at room temperature for upwards of fifteen months.

As hyphae developed the material was examined microscopically, and finally, when considerable dimensions had been attained, the fungus was treated with chromacetic fixative or absolute alcohol, embedded in wax, and microtomed.

\section{ÓBSERVATIONS.}

About one week after the spores were introduced into the flasks, hyphae had appeared in the cases of all three fungi.

Aspergillus niger showed no coloration due to the solution, and quickly died.

[Annals of Botany, Vol. XXXII. No. CXXVIII. Cctober, 1918.] 
Penicillium and Oidium both showed faint red, purple, or blue in the hyphae, according to the colour of the solution used.

From this time onwards growth of the fungus was always much quicker in the tannin preparations than in the Zsigmondy solution.

Oval or circular masses formed, sometimes on the surface, sometimes entirely submerged. Deeply tinted central regions developed with paler peripheral parts. As the gold accumulated in a region the colour gradually became blue. Material had to be cultivated for periods of four to nine months before the patches were sufficiently large to be embedded. For each method of preparation it was noticed that colour appeared in the hyphae more rapidly in the case of red solutions than in the case of blue. This point is of interest since it is known that the red solutions contain smaller particles (3), and diffuse more rapidly than the blue (4).

After material had been kept for ten to twelve months it was common to find the conidial stage again reached. Great development of intercalary spores was characteristic of most of the Oidium lactis cultures.

In no case was precipitation of the gold in the flasks observed, and there was a tendency for the liquids themselves to become alkaline. Thus six specimens prepared in December, I9I5, and tested in October, I9I6, all showed action on red litmus paper, although they had been prepared by means of tannic acid.

\section{CONTROLS.}

I. To find whether any of the observed colouring was due to the influence of tannic acid or gum arabic, material was grown upon these substances.

2. The alcohol, xylol, and oil of cloves used in the microscopic preparations were each added to separate portions of the solutions. No precipitation was produced.

The chromacetic fixative, when added in large amounts to specimens of the solution, produced a brownish precipitate, but this was quite unlike any colouring observed in the preparations.

3. Deeply coloured patches of fungi were soaked in chlorine water, with the result that the gold could be completely removed.

4. Cultures of the fungi used were grown upon tannic acid and gum arabic, then killed by soaking in absolute alcohol, well washed and added to solutions in order to find whether retention of the gold would result.

\section{EXamination of Sections.}

A striking feature of all sections was the small amount of protoplasm in the hyphae. In the alcohol preparations the plasmolysis of the protoplasm was helpful in determining the region of retention as the specimens 
were of extremely small diameter, the Oidium hyphae being the easier to examine.

The results were as follows:

\section{Absorption by Living Material.}

\section{Oidium lactis.}

(a) Gold present throughout the wall, as seen in cross-section.

(b) No gold retained in the protoplasm.

(c) Wall of spore coloured in same manner as wall of hyphae.
Penicillium glaucum.

Wall of hyphae stained throughout its thickness.

Protoplasm free from gold.

Wall of spore (which is cuticularized) without stain or surface deposit.

\section{Absorption by Dead Fungus.}

Some coloration seen in wall of hypha.

Distribution less uniform than in case of living material.

Slight precipitation of gold on limited areas of surface of protoplasm.

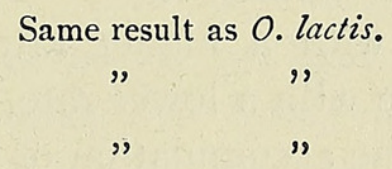

In all the specimens examined the gold was firmly retained and could not be removed during the embedding, or by long washing in such liquids as ether, acetone, and alcohol, of very varied surface tensions.

\section{Method of Removal and Retention of the Gold.}

Since the colloidal gold carries a negative charge and can be precipitated by the addition of electrolytes, two means by which the fungus acts suggest themselves:

(a) The fungus wall may possess a positive charge when in contact with the colloidal solution.

(b) Electrolytes may diffuse out of the cell at such a rate that they only suffice to coagulate the gold which has diffused into the wall and not so as to affect the liquid outside. Experiments were accordingly made to endeavour to find the nature of the charges upon the fungus cellulose in contact with water and with gold solutions.

A microscopic cover-slip was provided with electrodes of silver foil fixed in position with shellac and carrying fine wires. The material to be examined was placed on the slide and the whole connected with a reversing key and battery.

In some cases, when the current from four Leclanché cells was used, a well-marked migration of tiny pieces of hyphae and of spores took place, this movement being immediately reversed upon reversing the current.

The direction of migration, and consequently the charges, were varied; thus of twelve cultures examined, six showed a negative charge, three no charge, while three showed a slight positive charge.

The first suggestion of an electrical explanation was therefore not supported. 
The only evidence at present in support of the second suggestion is the final alkalinity of the tannic acid preparations after all the gold has been removed by the fungus.

\section{SUMMARY.}

I. Conidia of Penicillium glaucum and Oidium lactis can develop in colloidal gold solutions which contain tannin or gum arabic.

2. The living fungus, during growth, removes the metal from the solution. Retention occurs in such walls as are not cuticularized.

3. The process goes on more irregularly when masses of dead fungus are introduced into solutions.

4. Solutions with a higher rate of diffusion colour the fungus more quickly than those with a lower rate.

In all cases the accumulation of gold finally produces a blue coloration.

5. No explanation of the process can be given.

In conclusion the writer wishes to express her best thanks to Mr. Hatschek and Dr. Willows for many suggestions with regard to the physical preparations and determinations, and to Mr. H. B. Lacey for much help in the botanical matters.

The Sir John Cass Institute.

\section{BibLIOGRAPHY.}

1. Hatschek, E. : Introduction to Chemistry and Physics of Colloids, p. 8. I913.

2. Svenberg, The. : Die Methoden zur Herstellung kolloider Lösungen, p. 73.

3. FrEUNDLICH : Kapillar.Chemie, p. 364.

4. Ostwald : Grundriss der Kolloid-Chemie, p. 269. 


\section{$2 \mathrm{BHL}$ Biodiversity Heritage Library}

Williams, Maud. 1918. "Absorption of gold from colloidal solutions by fungi." Annals of botany 32, 531-534.

https://doi.org/10.1093/oxfordjournals.aob.a089690.

View This Item Online: https://www.biodiversitylibrary.org/item/238284

DOI: https://doi.org/10.1093/oxfordjournals.aob.a089690

Permalink: https://www.biodiversitylibrary.org/partpdf/320232

\section{Holding Institution}

Smithsonian Libraries

\section{Sponsored by}

Biodiversity Heritage Library

\section{Copyright \& Reuse}

Copyright Status: Not in copyright. The BHL knows of no copyright restrictions on this item.

This document was created from content at the Biodiversity Heritage Library, the world's largest open access digital library for biodiversity literature and archives. Visit BHL at https://www.biodiversitylibrary.org. 